\title{
Investigation of Salix alba and Populus tremula leaf litter decomposition in the area of Lake Balaton and Kis-Balaton Wetland
}

\author{
Brigitta Simon - Tamás Kucserka - Angéla Anda \\ University of Pannonia, Department of Meteorology and Water Management, Keszthely \\ simonbrigitta.georgikon@gmail.com
}

\begin{abstract}
SUMMARY
Plant litter decomposition in inland waters contributes significantly to nutrient load, particularly in still waters, such as shallow lakes and wetlands. The decomposition rates of Salix alba and Populus tremula leaf litter was examined in Lake Balaton and Kis-Balaton Wetland, using litter bag technique. Leaf litter was incubated in small $(Q=3 \mathrm{~mm})$ and large $(Q=900 \mu \mathrm{m})$ mesh size bags for the assessment of the relative contribution of macroinvertebrates to leaf litter decomposition. Dry mass, exponential decay coefficient and chemical parameters of water ( $\mathrm{pH}$, conductivity, $\mathrm{NH}_{4}{ }^{+}, \mathrm{NO}_{3}{ }^{-}, \mathrm{SO}_{4}{ }^{2-}, \mathrm{PO}_{4}{ }^{3-}, \mathrm{Cl}$ ) were determined. Leaf mass loss showed negative exponential pattern during the 168 days of the decomposition period. Leaf litter mass loss generally did not differ between the small and large mesh sizes, suggesting that macroinvertebrates generally have a negligible role in leaf decomposition in the winter period.
\end{abstract}

Keywords: leaf litter decomposition, Lake Balaton, Kis-Balaton Wetland, Salix alba, Populus tremula

\section{INTRODUCTION}

Leaf litter decomposition is a fundamental process, influencing material cycle (i.e. carbon, nitrogen, phosphorus etc.) in an ecosystem (Hoorens et al. 2003). Plant litter is an essential part of the food web and ecological functioning (Wallace et al. 1997, Gessner et al. 1999). Studies on plant decomposition have emphasized the role of internal (plant characteristics, for example lignin content) and external (environment, for example $\mathrm{pH}$ ) factors in the decomposition (Liu et al. 2016).

Salix alba and Populus tremula are the most common trees in the area of shallow lakes and wetlands in Hungary. Determining the decomposition rates of the dominant coastal trees will help us to answer whether the leaves falling into the lake serve as nutrient sink or source.

The general aim of this study was to estimate the decomposition rate of Salix alba and Populus tremula litter in winter with two different litter bags (small and large mesh sizes). Hypothesis that the litter of Salix alba and Populus tremula have the same decomposition rates were tested in the study areas (Lake Balaton and Kis-Balaton Wetland) by using different litterbags.

\section{MATERIAL AND MATHODS}

The study was conducted in Lake Balaton (surface area: $596 \mathrm{~km}^{2}$, average depth $\sim 3.3 \mathrm{~m}$ ) and Kis-Balaton Wetland $\left(68 \mathrm{~km}^{2}\right)$, which are located in southwestern Hungary (Tátrai et al. 2000). The sample sites were the Keszthely Bay $\left(17^{\circ} 14^{\prime} 46.3^{\prime \prime} \mathrm{E}\right.$ and $\left.46^{\circ} 43^{\prime} 32.1^{\prime \prime} \mathrm{N}\right)$

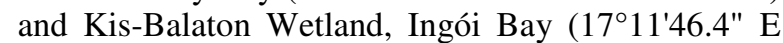
and $\left.46^{\circ} 38^{\prime} 37.4^{\prime \prime} \mathrm{N}\right)$.

Woody vegetation is dominated by Salix alba and Populus tremula around Lake Balaton and KisBalaton Wetland. Leaf litter decomposition rates of two species, Salix alba and Populus tremula were studied using litter bag technique in the field following the method of Bärlocher (2005), using two mesh size bags from 30 November 2016 to 5 May 2017. Leaf litter was washed and dried at $75^{\circ} \mathrm{C}$ until constant dry weight before the experiment. Leaf litter was transferred into 132 litter bags with the size of $15 \times 15 \mathrm{~cm}$ and two mesh sizes of $3 \mathrm{~mm}$ (large) and $900 \mu \mathrm{m}$ (small). The bags were incubated in situ at 1 $\mathrm{m}$ below the surface in the littoral zone and secured to plastic crates. This depth was sufficiently close to the sediment layer allowing invertebrate colonization. Three litter bags of each species were retrieved after 14, 112, 126, 140, 154 and 168 days. After sample collection, litter was transferred to the laboratory, and the foreign material was carefully removed by hand. After that, litter was washed using tap water, then oven-dried at $75{ }^{\circ} \mathrm{C}$ to constant weight. Macroinvertebrates in the coarse mesh bags were removed and preserved in $70 \%$ ethanol (KarádiKovács et al. 2015).

To make our decay rates comparable with other studies, not only the remaining leaf mass but also the exponential decay rates (Graca et al. 2005, Bärlocher 2005) were calculated:

$$
\mathrm{M}_{\mathrm{t}}=\mathrm{M}_{0} * \mathrm{e}^{-\mathrm{kt}}
$$

where $\mathrm{M}_{\mathrm{t}}=$ mass at time $\mathrm{t} ; \mathrm{M}_{0}=$ mass at time 0 ; $\mathrm{k}=$ exponential decay coefficient, and $\mathrm{t}=$ time in days. Based on their daily decay coefficients, leaves have been classified as "fast" $(\mathrm{k}>0.01)$, "medium" $(\mathrm{k}=0.005-0.001)$ and "slow" $(\mathrm{k}<0.005)$ (Petersen and Cummins 1974, Bärlocher 2005).

The halving times of the detritus were calculated using the formula proposed:

$$
\mathrm{T}_{\mathrm{H}}=\ln 2 * \mathrm{k}^{-1}
$$

Leaf mass losses (Lake Balaton and Kis-Balaton Wetland, in large and small mesh size litterbags) were compared using t-test. 


\section{RESULTS}

After half year of incubation, the two litter species underwent a relatively rapid mass loss, with the average remaining dry mass ranging from 44 to $63 \%$ of the initial dry mass depending on litter species and study sites. The mass loss followed a negative exponential pattern during the 168 days of the decomposition period.

Respect of $S$. alba leaves, $64 \%-53 \%$ of the initial dry mass remained in the litter bags after half year of incubation in Lake Balaton (Figure 1). The rate was the highest for Lake Balaton in the large mesh size litterbags. There was no significant correlation between the large and small mesh size leaf litter mass losses $(\mathrm{P}<0.8176)$. The reduction in the dry weight was the most prominent during the first 14 days in the large (46\%) and small (44\%) mesh size litterbags in Kis-Balaton Wetland. For $S$. alba, there was no significant correlation between the two mesh size litterbags $(\mathrm{P}<0.9932)$ in this water body.

The decomposition of $S$. alba detritus in Lake Balaton and Kis-Balaton Wetland did not show a significant difference between the large $(\mathrm{P}<0.3081)$ and small $(\mathrm{P}<0.3857)$ mesh size litterbags.

Figure 1: The remaining dry mass for Salix alba leaf litter during the 168 days long experiment in Lake Balaton (LB) and Kis-Balaton Wetland (KBW) $($ mean \pm SD, $n=3)$

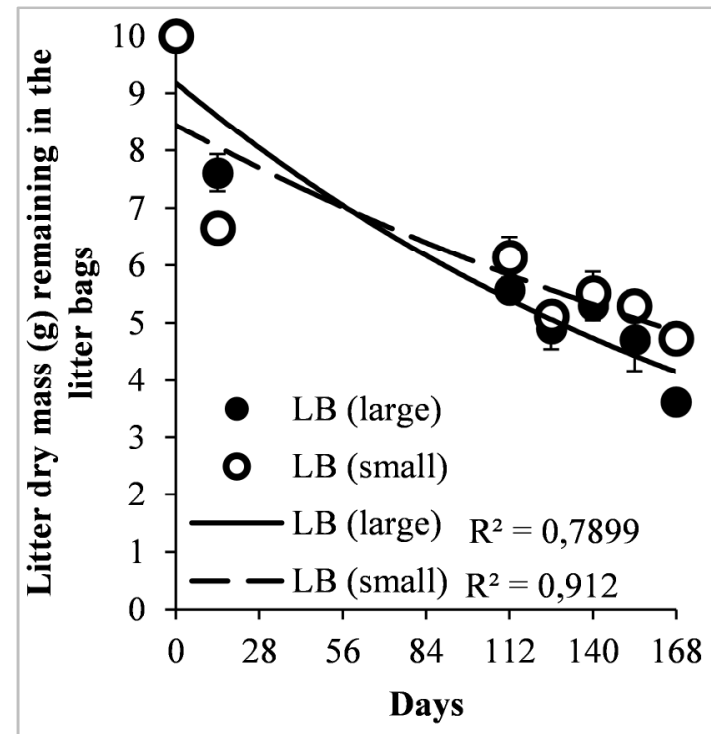

Changes in dry mass of $P$. tremula litter versus time are presented in Figure 2. In the first two weeks, the mean quantity of mass loss approximated $4 \mathrm{~g}$ in Lake Balaton in the large mesh size litterbag. During the 168 days long study period, leaves lost $73 \%$ of their original mass. We found that litter mass loss was not significantly different between the two mesh size litterbags $(\mathrm{P}<0.7382)$ in Lake Balaton. After 169 days of incubation in Kis-Balaton Wetland, the remaining $P$. tremula amount was $68 \%$ in the large mesh size litter bags, whereas in the small mesh size litterbag retained $40 \%$ of its original weight. The dry matter loss of P. tremula in the Kis-Balaton Wetland was not significantly greater in large mesh size litter bag than small mesh size litter bags $(\mathrm{P}<0.4222)$.

During our investigation, the patterns in the Lake Balaton and Kis-Balaton Wetland followed an exponential model generating not significant difference between the decomposition rates of detritus in the large $(\mathrm{P}<0.4120)$ and small $(\mathrm{P}<0.4725)$ mesh size litter bags.

For $S$. alba and $P$. tremula, the temporal changes in dry matter were similar between the two study sites,

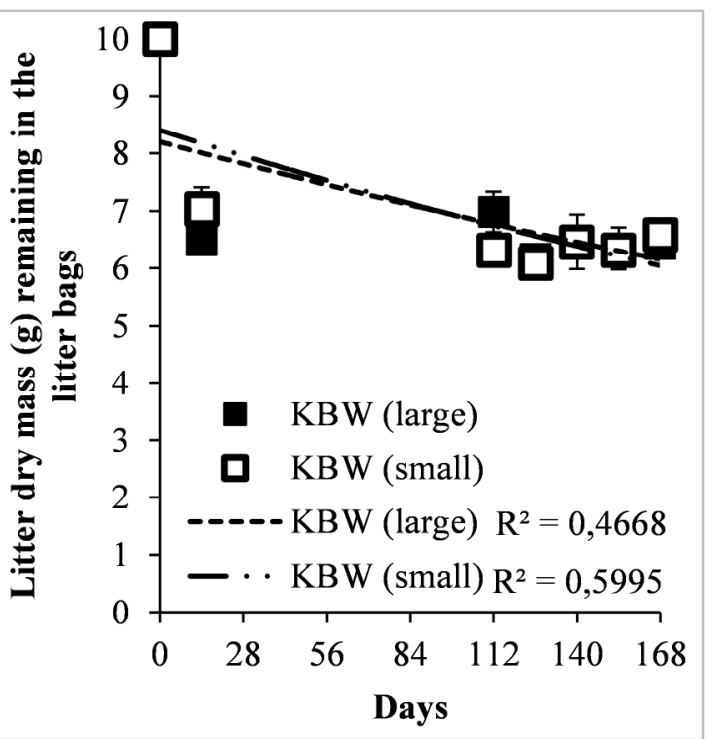

there were not any differences between the two species throughout. The amount of stem material remaining at the end of the experiment was slightly greater for $S$. alba compared to $P$. tremula $(\mathrm{P}<0.5668)$ in Lake Balaton in the large mesh size litterbags. In Kis-Balaton Wetland there was no significant difference between the two leaf species in small mesh size litterbags $(\mathrm{P}<0.4965)$.

The decomposition rates and the parameters obtained for the adjustment of the exponential model and the halving times of $S$. alba and $P$. tremula detritus are presented in Table 1. Decomposition rates obtained in Lake Balaton showed slightly higher values when invertebrates were excluded (small mesh size) in relation to large mesh. K-values of $P$. tremula leaves were high in Lake Balaton (large and small mesh size litterbag). The k-values of $P$. tremula leaves were larger than that of for $S$. alba in Kis-Balaton Wetland in two mesh size litterbags. In Lake Balaton, k-values of $P$. tremula were higher than the corresponding value for $S$. alba in the large and small mesh size litterbags. 
Figure 2: The remaining dry mass for Populus tremula leaf litter during the 168 days long experiment in Lake Balaton (LB) and Kis-Balaton Wetland $(K B W)($ mean $\pm S D, n=3)$
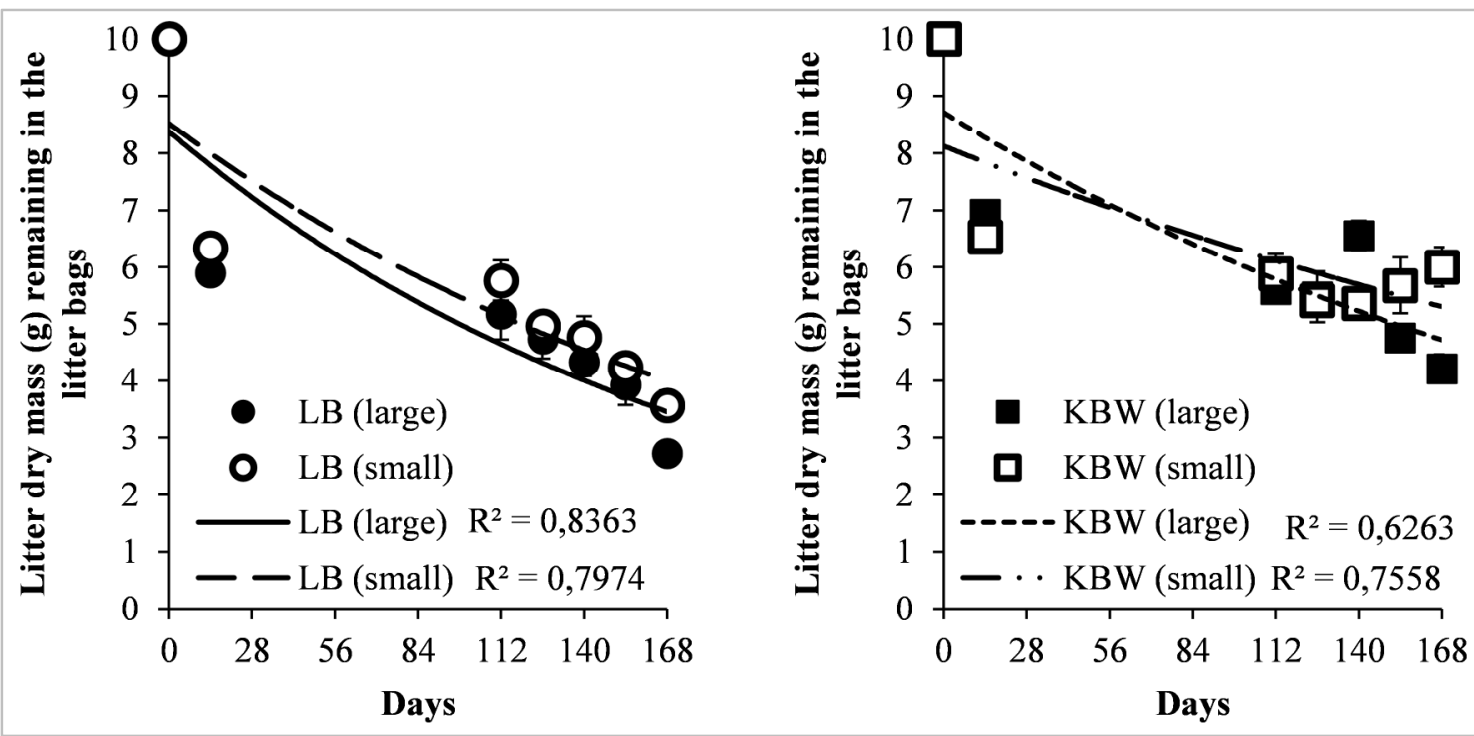

Table 1

Decomposition coefficients (k) and halving times of Salix sp. and Populus sp. in Lake Balaton and Kis-Balaton Wetland

\begin{tabular}{|c|c|c|c|c|c|}
\hline & Sample site & Litterbag mesh size & $\begin{array}{l}\text { Exponential decay } \\
\text { coefficient } \pm \text { SD }\end{array}$ & $\begin{array}{l}\text { Decomposition } \\
\text { rate }\end{array}$ & $\begin{array}{l}\text { Halving time } \\
\text { (day) }\end{array}$ \\
\hline \multirow{4}{*}{ Salix alba } & \multirow{2}{*}{ Lake Balaton } & large & $0.0081 \pm 0.0051$ & medium & 85 \\
\hline & & small & $0.0090 \pm 0.0090$ & medium & 77 \\
\hline & \multirow{2}{*}{ Kis-Balaton Wetland } & large & $0.0081 \pm 0.0102$ & medium & 86 \\
\hline & & small & $0.0073 \pm 0.0080$ & medium & 95 \\
\hline \multirow{4}{*}{ Populus tremula } & \multirow{2}{*}{ Lake Balaton } & large & $0.0121 \pm 0.0114$ & fast & 57 \\
\hline & & small & $0.0105 \pm 0.0100$ & fast & 66 \\
\hline & \multirow{2}{*}{ Kis-Balaton Wetland } & large & $0.0086 \pm 0.0079$ & medium & 81 \\
\hline & & small & $0.0089 \pm 0.0100$ & medium & 78 \\
\hline
\end{tabular}

In the present study, all physical and chemical parameters of the water (Table 2) had only little fluctuations. All $\mathrm{pH}$ values were slightly alkaline, it was higher in Lake Balaton compared to Kis-Balaton Wetland. The conductivity did not vary as the experiment progressed, and the values of the two study sites were close to each other. Concentrations of $\mathrm{NH}_{4}^{+}$were found to differ significantly $(\mathrm{P}<0.0026)$. $\mathrm{PO}_{4}{ }^{3-}, \mathrm{SO}_{4}{ }^{2-}$ and $\mathrm{Cl}^{-}$concentrations in Kis-Balaton Wetland exceeded those in Lake Balaton.

Table 2

Changes in the main chemical parameters of water during the decomposition period in Lake Balaton and Kis-Balaton Wetland

\begin{tabular}{lcc}
\hline & Lake Balaton & $\begin{array}{c}\text { Kis-Balaton } \\
\text { Wetland }\end{array}$ \\
\hline $\mathrm{pH}$ & $8.3 \pm 0.64$ & $7.8 \pm 0.41$ \\
Conductivity $\left(\mu \mathrm{S} \mathrm{cm}^{-1}\right)$ & $654 \pm 47.5$ & $753 \pm 124.1$ \\
$\mathrm{NH}_{4}{ }^{+}\left(\mathrm{mg} \mathrm{l}^{-1}\right)$ & $0.42 \pm 0.40$ & $1.4 \pm 1.24$ \\
$\mathrm{SO}_{4}{ }^{-2}\left(\mathrm{mg} \mathrm{l}^{-1}\right)$ & $94 \pm 37.4$ & $74 \pm 60.5$ \\
$\mathrm{PO}_{4}{ }^{3-}\left(\mathrm{mg} \mathrm{l}^{-1}\right)$ & $0.28 \pm 0.06$ & $0.72 \pm 0.41$ \\
$\mathrm{Cl}^{-}\left(\mathrm{mg} \mathrm{l}^{-1}\right)$ & $21.2 \pm 9.4$ & $13.2 \pm 3.7$ \\
\hline
\end{tabular}

\section{DISCUSSION}

Our results have an importance in the nutrient management of the ecosystem in Lake Balaton, as it provides information on the degradation dynamics of leaves from woody vegetation, which adds extra nutrients to the water. The $3 \mathrm{~mm}$ mesh size facilitates the action of macro- and meso-invertebrates, which accelerates fragmentation, catabolism and leaching (Danell and Sjöberg 1979, Brock et al. 1985, Neely 1994). Under our experimental conditions, the results indicate that the activity of invertebrates is not essential to increase the decomposition rate for $S$. alba and $P$. tremula in winter season.

At both study sites the decomposition rates of $S$. alba and $P$. tremula were generally less than in the most other studies respect of the same species. Ágoston-Szabó et al. (2014) investigated the decomposition dynamics of $S$. alba in Nyéki-HoltDuna. Their results showed that $31 \%$ of the initial dry mass remained in the litterbags after 140 days of incubation and decomposition rates showed slightly higher values $(0.0110 \pm 0.0009)$ than in our study. Kvalues of $S$. alba leaves were also slightly higher the 
study in Baldy et al. (1995) ( $\mathrm{k}=0.0091)$. However, in the Garrone River experiment, Chauvet (1987) got a lower decomposition rate $(\mathrm{k}=0.0054)$ than ours. MoraGómez et al (2018) investigated decomposition of $P$. nigra leaf litter in a temperate permanent stream (Ave River) for 21 days. Their results showed that decomposition rate of $P$. nigra was 0.047 , which value is much higher than ours. Another study (Dunck et al. 2015) shows the decomposition dynamics of $P$. tremula in five streams of the Ave River. Their values ranged from $\sim 0.014$ to 0.042. Abril et al. (2016) researched $P$. tremula leaf litter decomposition in selected habitat types: running waters, isolated pools and moist and dry streambed sediments. Running waters had a slightly higher decomposition rate $(0.053 \pm 0.003)$ than isolated pools $(0.044 \pm 0.005)$, furthermore a higher decomposition rate was observed in the moist sediments $(0.013 \pm 0.001)$ than in the dry sediments $(0.009 \pm 0.002)$.
Differences may also be partially due to the timing and type of the study sites (lake, river, wetland, etc.) (Asaeda and Nam 2002). The setup of the experiment in spring, as opposed to winter, results faster mass loss (Wrubleski et al. 1997). The timing of material collection, and the water content of the leaves (dried or fresh) may also contribute to the observed fluctuate of leaf litter decay rates (Gessner 1991).

Decomposing processes result in the release of available nutrients in water (Bärlocher 2005), which probably contributes to the high primary production rates observed in the Lake Balaton and Kis-Balaton Wetland.

\section{ACKNOWLEDGMENTS}

The publication is supported by the EFOP-3.6.3VEKOP-16-2017-00008 project. The project is cofinanced by the European Union and the European Social Fund.

\section{REFERENCES}

Abril, M.-Muñoz, I.-Menéndez, M. (2016): Heterogeneity in leaf litter decomposition in a temporary Mediterranean stream during flow fragmentation. Science of the Total Environment. 553: 330-339.

Ágoston-Szabó, E.-Schöll, K.-Kiss, A.-Berczik, Á.-Dinka, M (2014): Decomposition of Willow Leaf Litter in an Oxbow Lake of the Danube River at Gemenc, Hungary. Acta Zoologica Bulgarica. 7: 197-202.

Asaeda, T.-Nam, L. H. (2002): Effects of rhizome age on the decomposition rate of Phragmites australis rhizomes. Hydrobiologia. 485: 205-208.

Baldy, V.-Gessner, M. O.-Chauvet, E. (1995): Bacteria, fungi and the breakdown of leaf litter in a large river. Oikos. 74: 93-102.

Bärlocher, F. (2005): Leaf Mass Loss Estimated by Litter Bag Technique. [In: Graça, M.A.S. et al. (eds.) Methods to Study Litter Decomposition - a Practical Guide.] Springer. Dordrecht. The Netherlands. 37-42.

Brock, T. C. M.-DeLyon, M. J. H.-Van Laar, E. M. J. M.-Van Loon, E. M. M. (1985): Field studies on the breakdown of Nuphar lutea (L.) SM. (Nymphaeaceae), and a comparison of three mathematical models for organic weight loss. Aquat. Bot. 21: $1-22$.

Chauvet, E. (1987): Changes in chemical composition of alder, poplar and willow leaves during decomposition in a river. Hydrobiologia. 148: 35-44.

Danell, K.-Sjoberg, K. (1979): Decomposition of Carex and Equisetum in northern Swedish lake: dry weight loss and colonization by macroinvertebrates. Journal of Ecology. 67: 191-200.

Dunck, B.-Lima-Fernandes, E.-Cassio, F.-Cunha, A.-Rodrigues, L.-Pascoal, C. (2015): Responses of primary production, leaf litter decomposition and associated communities to stream eutrophication. Environmental Pollution. 202: 32-40.

Gessner, M. O.-Chauvet, E.-Dobson, M. (1999): A perspective on leaf litter breakdown in streams. Oikos. 85: 377-384.
Gessner, M. O. (1991): Differences in processing dynamics of fresh and dried leaf litter in a stream ecosystem. Freshwater Biology. 26: 387-398.

Graca, M. A. S.-Bärlocher, F.-Gessner M. O. (2005): Methods to Study Litter Decomposition: A Practical Guide.

Hoorens, B.-Aerts, R.-Stroetenga, M. (2003): Does initial litter chemistry explain litter mixture effects on decomposition? Oecologia. 137: 578-586.

Karádi-Kovács, K.-Selmeczy, G. B.-Padisák, J.-Schmera, D. (2015): Food, substrate or both? Decomposition of reed leaves (Phragmites australis) by aquatic macroinvertebrates in a large shallow lake (Lake Balaton, Hungary). Ann. Limnol. Int. J. Lim. 51: 79-88.

Liu, X.-Huang, Q. H.-Jian, H. L.-Song, N. (2016): Effects of visible light radiation on macrophyte litter degradation and nutrient release in water samples from a eutrophic shallow lake. Chemistry and Ecology. 32. 10: 961-975.

Mora-Gómez, J.-Duarte, S.-Cássio, F.-Pascoal, C.-Romaní, M. A. (2018): Microbial decomposition is highly sensitive to leaf litter emersion in a permanent temperate stream. Science of the Total Environment. 621: 486-496.

Neely, R. K. (1994): Evidence for positive interactions between epiphytic algae and heterotrophic decomposers during the decomposition of Typha latifolia. Arch. Hydrobiol. 129: 443-457.

Petersen, R. C.-Cummins, K. W. (1974): Leaf processing in a woodland stream. Freshwater Biology. 4: 343-368.

Tátrai, I.-Mátyás, K.-Korponai, J.-Paulovits, G.-Pomogyi, P. (2000): The role of the Kis-Balaton Water Protection System in the control of water quality of Lake Balaton. Ecol Eng. 16: 73-78.

Wallace, J. B.-Eggert, S. L.-Meyer, J. L.-Webster, J. R. (1997): Multiple trophic levels of a forest stream linked to terrestrial litter inputs. Science. 277: 102-104.

Wrubleski, D. A.-Murkin, H. R.-van der Valk, A. G.-Nelson, J. W. (1997): Decomposition of emergent macrophyte roots and rhizomes in a northern prairie marsh. Aquatic Botany. 58: 121134. 